\begin{tabular}{|l|l} 
Ardeth \\
A magazine on the power of the project \\
Col $\mathbf{2 0 2 0}$ \\
Contingency
\end{tabular}

\title{
Architectures of an "Otherwise": Inhabiting Displacement
}

Somayeh Chitchian, Maja Momic, HafenCity University Hamburg, Department of Urban Design - maja [dot] momic [at] hcu-hamburg [dot] de and Shahd Seethaler-Wari

\section{(2) OpenEdition \\ 12 Journals}

\section{Electronic version}

URL: http://journals.openedition.org/ardeth/1240

ISSN: 2611-934X

\section{Publisher}

Rosenberg \& Sellier

Printed version

Date of publication: 1 September 2020

Number of pages: $249-255$

ISSN: 2532-6457

\section{Electronic reference}

Somayeh Chitchian, Maja Momic, HafenCity University Hamburg, Department of Urban Design - maja [dot] momic [at] hcu-hamburg [dot] de and Shahd Seethaler-Wari, "Architectures of an "Otherwise":

Inhabiting Displacement », Ardeth [Online], 6 | 2020, Online since 01 November 2020, connection on 13 November 2020. URL : http://journals.openedition.org/ardeth/1240 


\section{Architectures of an "Otherwise": Inhabiting Displacement}

\section{Commentary}

(1) Somayeh Chitchian

(2) Maja Momic

(3) Shahd Seethaler-Wari
Abstract

This concept paper aims to destabilize the limits and delineations of conventional architectural thinking by disclosing its ambiguities and contingencies through the centralization of the inhabitation-displacement nexus and, by extension, the figure of the inhabitant. Building upon our January 2019 workshop at the Max Planck Institute for the Study of Religious and Ethnic Diversity in Germany, entitled: Inside Out - Outside In: Shifting Architectures of Refugee Inhabitation, its keynote interventions by Prof. Anooradha Iyer Siddiqi and Prof. Romola Sanyal, together with the vast array of topics and methodologies brought to the table by our presenters, we primarily argue towards the concept of inhabitation as an epistemic shift of both the site and the subject of architectural (knowledge) production. Shifting our focus particularly to the sites and subjects of displacement (i.e., 'the refugee'/ 'the migrant' and beyond) enabled us to centralize the concept of inhabitation as a modality of the architectural spatial production of an otherwise through the prime subject figure of architectural authorship: the inhabitant.
Affiliation

(1) Harvard

University,

Graduate School of Design

(2) HafenCity

University

Hamburg,

Department of

Urban Design

(3) Max Planck Institute for the Study of

Religious and

Ethnic Diversity,

Department of socio-cultural diversity

Contacts:

(1) schitchi [at] gsd [dot] harvard [dot] edu

(2) maja [dot] momic [at] hcuhamburg [dot] de (3) wari [at] $\mathrm{mmg}$ [dot] mpg [dot] de

DOI:

10.17454/ARDETH06.18

ARDETH\#06 

http://events.mmg. mpg.de/inside-outoutside-in/

\section{Introduction}

In January, 2019, the authors of this paper organized the workshop Inside Out - Outside In: Shifting Architectures of Refugee (In)habitation at the Max Planck Institute for the Study of Religious and Ethnic Diversity in Göttingen, Germany ${ }^{1}$. The workshop hosted adept scholars and practitioners working at the intersection of architectural research and refugee/ migration studies. Around twenty architects, academics, postdocs, and doctoral students shared their work on the topic, presenting various themes, theories, methodologies, geographies and scales of research. Our keynote panel comprised a talk by Prof. Anooradha Iyer Siddiqi (Barnard College, Columbia University), entitled "Decoloniality in the Camp and the University," and a response by Prof. Romola Sanyal (London School of Economics), entitled "Unsettling Architectural Narratives of Refuge: From Camps to Cities."

Building upon this workshop, this piece centralizes the concept of inhabitation as a contingent modality of architectural spatial production of an otherwise (Povinelli, 2011, 2012, 2014, 2017) through the prime subject figure of architectural authorship: the inhabitant. The sheer nakedness of conditions of displacement and abandonment visibilizes these alternate architectures and potentialities of spatial production, otherwise invisible to and unseen by the discipline of Architecture. As Elizabeth Povinelli states in her work on the anthropology of the otherwise, "to build is to build into existence the possibility of an otherwise" (Povinelli, 2014; emphasis added). The aim is to understand "the dwelling of potentiality", the ability "to think and see otherwise" (Povinelli, 2012), the possibility for an alternate "stitching" together of space, an alternate spatial arrangement which "installs its own possible derangements and rearrangements," thus "creating new enclosures” while "allowing new worlds to emerge” (Povinelli, 2011).

Furthermore, this piece aims to conceptualize architecture beyond its association with the design and the materiality of the built environment alone, but rather as a domain, zone, or plane of arrangements (Povinelli, 2014,2017 ) through which power, politics, and subject positions are constantly formed, encountered, and negotiated. By particularly focusing on alternate modalities of spatial inhabitation and authorship in conditions of displacement and abandonment, the bareness of the situation allows us to conceptualizes architecture as a (political) field of power; of simultaneous care and violence, emplacement and displacement, construction and deconstruction, sheltering and uprooting, enclosure and abandonment. Furthermore, in this double modality of operation, it becomes a porous space, plane, or a position of power for the potential emergence of different subject positions of spatial production and authorship, or, in the words of Povinelli, the potentiality to "figure space - ... create worlds - ... figured by figurated space” (2011). 
From Architecture(s) of Displacement...

Architecture(s) of displacement (cf. MOMA, 2016; Oxford Refugee Studies Centre, 2017-2018), if thematized or studied at all, is oftentimes associated with institutionalized spaces of shelter. It is primarily centered on the binarism of the formal, institutional, humanitarian, and overall 'authored' (Siddiqi, 2018) understandings of shelter in relation to the 'informal', makeshift, and self-made modalities of thereof (Martin et al., 2019). Additionally, the subject inhabiting these so-called spaces of displacement is oftentimes that of 'the refugee', or more broadly 'the migrant', as the prime embodiment of the contemporary subject position of displacement and dispossession.

While this framing of architectures of displacement is analytically valuable due to the sheer visibility and nakedness of the violent conditions it exposes, it can be considered limited, if not problematic, in multiple ways as described below.

First, architectural design is often associated with the emplacement or shelter of displaced populations coming 'from outside' of state- and/ or urban territories, calling upon architects, technocrats, and state actors for a contingency plan to 'contain' the crisis. As such, Architecture presents itself as a force coming in after displacement has occurred to house, shelter, protect, and care and, by extension, to contain the displaced. This type of framing, however, neglects architecture as a prime politico-spatial force that induces conditions of displacement and occupation in the first place (Weizman, 2007): A force which strategically de-constructs, dis-places, kills, and deprives the subject of their initial modalities of habitation. Thus, architecture's complicity in inducing displacement (e.g. a prime tool of colonial and imperial expansions and territorial occupations, to war-making, uneven profit-driven development and speculations, gentrification, etc.) and, as a result, producing displaced populations (both internally and internationally, from displaced populations to marginalized urban poor, homelessness, etc.) should be central to any historical, theoretical, and/ or practical endeavor in the field of architecture, and the study of the built environment in general.

Second, conventional Architectural thinking is oftentimes framed as an object-based discipline, using the container as its archetypal problem solution. If the problem of displacement (homelessness/ dispossession/ marginalization) gets linearly paired with the solution of containment and shelter (room/ box), we easily (a) overlook the multiscalar processes operationalizing and replicating both displacement and its containment - from the smallest scale of the architectural detail to the broadest urban, infrastructural, and regional levels of analyses. Moreover, we (b) lose sight of the social worlds and urban entanglements constituting the creation, operation, and adaptations of multiple 'containers' put next to each other (Herz, 2012). Furthermore, thinking of architectural space as a finished product or a static solution to a complex process of multiple power negotiations impedes us from connecting the 'box' to the different 
modalities of its formation (beyond the planned vs. unplanned or formal vs. informal binaries) and its subsequent operationalization (later use, appropriation, and inhabitation). Thus, this approach fundamentally neglects the affective, the everyday, the personal, and experiential dimensions and interactions with the built environment and their constant de-arrangements and rearrangements from below.

Third, conventional Architectural thinking impedes us from considering the temporal dimensions of inhabitation and shelter: Supposedly temporary shelters (often implementing ready-made architectural solutions due to alleged lack of time) often become protracted living spaces for many and eventually permanent components of the broader urban fabric in which they are situated.

Fourth, architectures of displacement foster a humanitarian, interventionist, and authored understanding of architectural spatial production, particularly in conditions of mass displacement, and thus create a dualism between the figure of the so-called 'architect' and that of 'the refugee' (or 'the migrant') - putting one at the giving and the other at the receiving end of technical expertise and, by extension, knowledge. Limiting architectural authorship to state (and non-state, supra-state) institutions and their representative architects, designers, planners, and technocrats prevents the analytical shift from considering the inhabitants of spaces of refuge (Sanyal, 2014) as the prime authors and agents, writing and creating alternate histories and modalities of emplacement and shelter (Siddiqi, 2018); what we have called here the architectural inhabitation of an otherwise. To address this inaccuracy, we argue for an epistemic shift of the sites and subjects of (architectural) knowledge production: From the camp to the city and to the broader urban and regional scale, and from refugees (or migrants) to other marginalized urban populations (Sanyal, 2014, 2016). This analytical focus on 'the refugee' as classified by the state limits the possibility of an intersectional approach with other spaces and subjects of displacement (e.g., the internally displaced, the urban poor, etc.) and the dispossession and marginalization happening beyond, and in relation to 'the refugee'. As our keynote speakers argued, it is of vital importance to put refugee populations alongside the urban poor, to extend their livelihoods outside of the camp in parallel to other marginalized urban populations who, in many cases, inhabit the same spaces of abandonment.

\section{...Towards Inhabitation as an Epistemic Shift}

While the delineation of space - the formation and territorialization of an inside in relation to an outside - forms one of the fundamental components of the architectural form, spatial demarcation and bordering and its subsequent 'unauthorized' crossing is fundamental to the formation and categorization of the refugee/ migrant/ displaced subject as well. However, through the concept of inhabitation, we argue towards a different understanding of territorialization and spatial demarcation, one 
in which the inhabitation and rearrangement of space - the possibility of building an otherwise into existence - actively creates agents and authors of architecture. These processes of spatial (re)arrangements continually create their own otherwises, pulling in and altering that which surrounds them, and thus giving power and political force to new planes of existences (Povinelli, 2014).

Accordingly, this piece centralizes the concept of inhabitation as an alternate modality of architectural spatial production by and through the inhabitant. While habitat could be considered as merely a container, a function, a brutal material reality, habiter, on the other hand, expresses an activity, a situation, a practice, linked to the urban and social space (Lefebvre, 1965; Elden, 2004). Focusing on inhabitation as a multi-scalar socio-spatial process, embodied within, outside, and alongside the socalled formal and institutional frameworks of architectural production allows us to deconstruct the framing of architecture and displacement in multiple ways. This analytical lens enables the problematization of the binarisms and dualities of: Architecture vs. urbanization of refuge; the camp vs. the city; the architect vs. the refugee; the institutional vs. the 'informal'; the material vs. the experiential; internal vs. international displacement. Such a lens allows for the understanding of the interdependencies and co-constitutive nature of each of these categories of analysis, and thus provides an empirical and theoretical framework for bridging the dualities mentioned.

Additionally, inhabitation as a framework of analysis encourages the deconstruction of the techno-material foundations of architectural production by positing it as a mode of subject position in and of space. Through inhabitation, alternate modalities of architecture are produced, authorship falls in the hands of the many (beyond technocrats and the state), and thus inhabitation acts as a mediation between conditions of dis-placement and place-making from below. Furthermore, the concept of inhabitation allows us to tackle the question of power inherent in the control, demarcation, and formation of architectural space. It can be conceptualized as a process of spatial (re)production embodying political power and agency through its control and authorship. For example, on the one level, the entanglement of the power and agency to be on-the-move and the autonomy to inhabit alternate spatialities while, on the other, the power to control, displace and contain those constantly shaping otherwises of spatial inhabitation. Thus, one could argue for the constant, oftentimes violent, entanglement of the displacement-inhabitation operational nexus and its spatial manifestations.

Finally, considering inhabitation as a multi-scalar analytical category of spatial production allows for the cross-connection of the various scales through which both displacement and inhabitation occur. Time and again, architectural thinking has a scalar limitation which prevents the cross-connection of its sociospatialities to other scales and geographies of operation. Fundamental is to surpass the technical, boxed, and form- 
based understandings of its formation and operation in order to be splintered, infrastructuralized, and more broadly urbanized (Cowen, 2017; Graham and Marvin, 2001; Graham and McFarlane, 2015; Sturlaugson, 2018). Additionally, regarding the 'refugee' as an isolated category limits the cross-connection of other modalities of mobilization and capture embodied by the (im)migrant, the urban marginalized poor, the colonial and imperial histories of mobilization and capture, etc. Understanding inhabitation as being infrastructural gives one possibility to unbound our object-oriented study of architectural buildings and/ or cities, and to move towards an infrastructural/ relational approach which connects both and beyond.

In sum, inspired by our workshop's keynote lectures, together with the vast array of topics and methodologies brought to the table by our presenters, we primarily argue towards the concept of inhabitation as an epistemic shift of both the site and the subject of architectural knowledge production. Inhabitation, in essence, is a contingent process of spatial authorship and (re)production, a yet-to-come design of the unlabeled architect, a yet-to-be-written spatial story of its invisibilized author (cf. Siddiqi, 2018), an otherwise constantly to be written and rewritten, arranged, de-arranged, and re-arranged in an entangled web of connections. It is not to be fetishized through 'crisis' discourses of 'exceptionality'. Rather, the parameters for its emergence are already present, already designed, yet often omitted by the gaze of the discipline of Architecture.

The question however remains, what are the possibilities, but also the limits, of Architecture to unlearn and rethink the boundaries and parameters of its predefined authorship and to fundamentally recast a different disciplinary approach altogether? The first step towards an architecture of an otherwise would be to recast a new author: the inhabitant.

\section{References}

Architectures of Displacement (2017) [Research project], Oxford Refugee Studies Centre, Department of International Development 2017 - 2018 [Online]. Available at: https://www.rsc.ox.ac.uk/research/architectures-of-displacement [Accessed: 1 November 2019].

Cowen, D. (2017), Infrastructures of empire and resistance, "Verso Blog” [Online]. Available at: https://www.versobooks.com/blogs/3067-infrastructures-of-empire-and-resistance [Accessed: 20 January 20 2018].

Elden, S. (2004), Understanding Henri Lefebvre, London, A\&C Black.

Graham, S., Marvin, S. (2001), Splintering Urbanism, New York, Routledge. Graham, S., McFarlane, C. (eds) (2015), Infrastructural Lives: Urban infrastructure in context, New York, Routledge.

Herz, M. (ed.) (2012), From Camp to City: Refugee camps of the Western Sahara, Basel, Lars Müller Publishers.

Insecurities: Tracing Displacement and Shelter (2016) [Exhibition]. Theme "The Architecture of Displacement”, Museum of Modern Art, New York City. 1 October 2016 - 22 January 2017.

Lefebvre, H. (1965), Métaphilosophie: Prolégomènes, Paris, Éditions de Minuit. 
Martin, D., Minca, C., Katz, I. (2019), Rethinking the camp: On spatial technologies of power and resistance, "Progress in Human Geography", vol. 42, n. 2, pp. 183-204. Povinelli, E. A. (2011), Routes/Worlds, “e-flux journal”, n. 27 [Online]. Available at: https://web.archive.org/web/20111013071516/http://www.e-flux.com/journal/ view/244\#_ftn15 [Accessed: 10 November, 2019].

Povinelli, E. A. (2012), The will to be otherwise / The effort of endurance, "The South Atlantic Quarterly”, vol. 111, n. 3, pp. 453-475.

Povinelli, E. A. (2014), Geontologies of the otherwise, "Society for Cultural Anthropology", Theorizing the Contemporary - Fieldsights, 13 January [Online]. Available at: https://culanth.org/fieldsights/geontologies-of-the-otherwise [Accessed: November 6, 2019].

Povinelli, E. A. (2017), Geontologies: The Concept and Its Territories, "e-flux Architecture”, n. 81 [Online]. Available at: https://www.e-flux.com/journal/81/123372/ geontologies-the-concept-and-its-territories/ [Accessed: 6 November 2019].

Sanyal, R. (2014), Urbanizing refuge: Interrogating spaces of displacement, in "International Journal of Urban and Regional Research”, vol. 38, n. 2, pp. 558-572.

Sanyal, R. (2016), From camps to urban refugees: Reflections on research agendas, "International Journal of Urban and Regional Research", November.

Siddiqi, A. Iyer (2018), Writing with: Togethering, difference, and feminist architectural histories of migration, in Structural Instabilities, "e-flux Architecture" [Online]. Available at: https://www.e-flux.com/architecture/structural-instability/208707/writing-with/ [Accessed: 10 December 2018].

Sturlaugson, B. (2018), The supply chains of architecture, "Places Journal" [Online]. Available at: https://placesjournal.org/article/the-supply-chain-of-architecture/?cn-reloaded=1 [Accessed: 3 December, 2018].

Weizman, E. (2007), Hollow Land: Israel's Architecture of Occupation, London, Brooklyn (NY), Verso. 